\title{
PUSAT KREATIVITAS ANAK DI PONTIANAK
}

\author{
Adilla Chairiah ${ }^{1}$, Lestari ${ }^{2}$, Irwin $^{3}$ \\ ${ }^{1}$ Mahasiswa, Jurusan Arsitektur, Fakultas Teknik, Universitas Tanjungpura. \\ adillach99@gmail.com \\ ${ }^{2}$ Jurusan Arsitektur, Fakultas Teknik, Universitas Tanjungpura \\ ${ }^{3}$ Jurusan Arsitektur, Fakultas Teknik, Universitas Tanjungpura
}

Naskah diajukan pada: 22 Juni 2021

Naskah revisi akhir diterima pada: 25 Juni 2021

\begin{abstract}
Abstrak
Anak merupakan penerus masa depan bangsa yang harus dibekali dengan ilmu pengetahuan dan pendidikan yang menunjang. Salah satu faktor yang mempengaruhi perkembangan anak adalah potensi dan minat yang berpengaruh terhadap kreativitas seorang anak. Kreativitas merupakan hal yang penting bagi seorang anak karena berguna sebagai kebutuhan manusia untuk berkreasi, mengekspresikan diri dan pikiran dalam memecahkan suatu masalah dan lainnya. Kegiatan kreativitas di sekolah sangat terbatas yaitu 4-5 jam dikarenakan kurikulum serta struktur program ketat dan terikat (Kemendikbud, 2012). Serta minimnya fasilitas yang mendukung pengembangan kreativitas anak di Pontianak. Kondisi ini menunjukkan bahwa Pontianak membutuhkan fasilitas yang mendukung pengembangan kreativitas anak yaitu Pusat Kreativitas Anak di Pontianak sebagai wadah kegiatan dalam pengembangan kreativitas. Metode perancangan Pusat Kreativitas Anak dimulai dari identifikasi masalah, pengumpulan data terdiri dari data primer yang didapat dari observasi lapangan dan sekunder didapat dari buku, jurnal dan lainnya. Data tersebut kemudian diolah dan dianalisis yang menghasilkan gambar pra perancangan. Penekanan perancangan adalah ramah anak yang mencakup aspek keamanan, kenyamanan, kebebasan serta merangsang potensi anak. Konsep ini menghasilkan desain bangunan 1 massa yang dinamis dengan bentuk lingkaran yang mengalami penambahan dan pengurangan bentuk. Penggunaan warna, bentuk, material serta dimensi yang tepat merupakan inti dari perancangan Pusat Kreativitas Anak di Pontianak.
\end{abstract}

Kata-kata Kunci: Anak, Kreativitas, Ramah Anak

\begin{abstract}
Children are the future successors of the nation who must be equipped with supporting knowledge and education. One of the factors that influence the development of children are children's creativity. Creativity is important for children because creativity is useful as a human need to be creative, creativity allows children to express themselves and thoughts in solving problem and many more. Creativity activities in schools are limited, namely 4-5 hours due to strict curriculum (Kemendikbud, 2012). The facilities that support the development of children's creativity in Pontianak is quite limited. This condition shows that Pontianak needs facilities that support the development of children's creativity, namely the Child Creativity Center in Pontianak. The design method starts from identifying the problem by looking at the issues, data collecting consists of primary data and secondary data, and then the data is analyzed which produced pre design drawing. The emphasis on the design is child-friendly which includes aspects of safety, comfort, freedom and stimulates children's potential. This concept produces a mass building design with a circular shape that has been transformed. The use of the right colors, shapes, materials and dimensions is the core of the design of the Children's Creativity Center in Pontianak.
\end{abstract}

Keywords: Children, Creativity, Child-friendly

\section{Pendahuluan}

Anak merupakan penerus masa depan bangsa yang harus dibekali dengan ilmu pengetahuan dan pendidikan yang menunjang. Ada dua faktor yang mempengaruhi perkembangan anak yaitu faktor dasar meliputi potensi dan minat serta faktor lingkungan meliputi keluarga, masyarakat, dan sekolah. Pengembangan potensi dan minat anak sangat berpengaruh terhadap kreativitas seorang 
anak. Kreativitas penting bagi seorang anak karena (1) Kreativitas sebagai kebutuhan manusia untuk berkreasi; (2) Kreativitas memungkinkan anak untuk mengekspresikan diri dan pikiran dalam memecahkan suatu masalah; (3) Kreativitas mempengaruhi emosi sosial anak; (4) Kreativitas sebagai upaya untuk meningkatkan kualitas diri (Atmiasri, 2019).

Kegiatan anak di sekolah sebagian besar diisi dengan kegiatan akademis yaitu 20-27 jam per minggunya, sedangkan 4-5 jam per minggunya diisi dengan kegiatan seni dan olahraga. Hal ini menunjukkan bahwa kurangnya waktu dan kegiatan anak untuk pengembangan kreativitas (Kemendikbud, 2012). Di Pontianak, fasilitas yang mendukung pengembangan kreativitas anak dapat terbilang terbatas. Fasilitas yang mendukung hanya sebatas fasilitas pendidikan formal pada umumnya yaitu sekolah. Kondisi ini menunjukkan bahwa Pontianak membutuhkan fasilitas yang mendukung pengembangan kreativitas anak.

Fasilitas pendidikan ramah anak adalah fasilitas dengan ruang dan lingkungan yang aman, nyaman, sehat dan kondusif, menerima anak apa adanya, dan menghargai potensi anak (Yulianto, 2016). Dari pernyataan tersebut dapat disimpulkan bahwa fasilitas pendidikan yang ramah anak harus mencakup aspek keamanan, kenyamanan serta merangsang potensi anak. Berdasarkan pemaparan di atas, maka dibutuhkan Pusat Kreativitas Anak di Pontianak sebagai wadah kegiatan dalam pengembangan kreativitas yang ramah anak serta merangsang potensi anak dalam beraktivitas.

\section{Kajian Pustaka}

Kreativitas adalah kemampuan seseorang untuk menghasilkan suatu komponen produk atau gagasan baru yang tidak ada sebelumnya. Kreativitas dapat berupa pemikiran imajinatif ataupun gabungan informasi dari sintesis pemikiran dan pengalaman si pemikir (Setyaningsih, 2004). Sedangkan menurut Munandar (2009) dalam Fakhriyani (2016) kreativitas adalah hasil dari interaksi individu dengan lingkungannya, kemampuan individu untuk menghasilkan kombinasi baru berdasarkan data, informasi, pengetahuan atau pengalaman seseorang selama hidupnya dari lingkungan sekolah, keluarga, sekolah dan masyarakat sekitar. Dari kedua definisi diatas dapat disimpulkan bahwa kreativitas adalah kemampuan seseorang untuk menghasilkan suatu gagasan baru yang berasal baik dari imajinasi maupun pengalaman seseorang selama hidupnya.

Adapun aktivitas yang mendukung pengembangan kreativitas menurut Fakhriyani (2016) adalah mendongeng, menggambar, bermain musik, bermain lilin, kolase, dan bermain balok. Mendongeng menjadi salah satu aktivitas yang berperan dalam pengembangan kreativitas anak. Menurut Parkinson (2011) dalam Abidin (2013) dongeng merupakan karya fiksi yang imajinatif sehingga dengan mendongeng, daya imajinasi seorang anak dapat berkembang. Daya imajinasi merupakan salah satu karakteristik kreativitas yang berguna bagi anak-anak untuk memecahkan suatu permasalahan serta kemampuan sains anak-anak. Menurut Indrati (2005) dalam Ariani et al. (2013) menggambar penting bagi seorang anak bagi perkembangan sisi kreatifnya, karena hal ini membantu seorang anak untuk mengekspresikan diri dan imajinasi tanpa batas. Pada saat menggambar, seorang anak dapat menyalurkan gagasan, emosi, minat dan seni serta imajinasinya. Bermain musik membantu anak mengekspresikan isi pikiran dan imajinasinya melalui improvisasi dan mengubah nada atau irama saat bermain alat musik, dengan bermain musik inilah anak akan lebih mengeksplor lingkungan sekitarnya yang tanpa disadari kreativitas dan imajinasinya berkembang dengan sendirinya (Yulianto et al., 2018). Menurut Jatmika (2012) dalam Rahmat \& Sum (2017) aktivitas bermain lilin atau playdough diantaranya sebagai berikut memipihkan, menggiling, menggulung, mencetak, dan membentuk lilin menjadi bentukan lain sesuai dengan imajinasi dan ide anak. Berkaitan dengan hal ini tentu saja mendorong perkembangan kreativitas seorang anak dan memecahkan suatu permasalahan melalui imajinasi anak dalam mengeksplor dan menciptakan bentuk-bentuk lilin. Bermain kolase dapat mengembangkan kreativitas anak melalui keterampilan anak menyusun dan merekatkan bahan-bahan seperti kertas, kain, biji-bijian dan sebagainya pada bidang kertas atau bidang lain. Kegiatan ini memberikan kebebasan anak untuk 
mengekspresikan diri dan membuat anak berfikir kreatif serta menggunakan imajinasi mereka sehingga menghasilkan kolase yang unik dan menarik (Devi, 2014). Menurut Winn \& Porcher dalam Fauziah (2017), balok adalah potongan kayu polos yang tidak dicat, dengan ukuran tebal dan panjangnya dua kali lebih besar dari tebalnya. Bermain balok termasuk ke dalam kegiatan konstruktif yang melibatkan anak membangun, memanipulasi dan mengeksplorasi, serta menciptakan bentukbentuk baru atau bangunan melalui susunan balok-balok, yang tidak hanya melatih anak memecahkan masalah tetapi juga memberikan kebebasan anak untuk berimajinasi serta mengembangkan ide kreatifnya.

Adapun aktivitas yang mendukung pengembangan kreativitas terdiri dari dua yaitu pengembangan kreativitas dalam bidang fisik dan pengembangan kreativitas dalam bidang seni (Sit et al., 2016). Kreativitas bidang fisik berkaitan dengan keterampilan motorik anak. Keterampilan tersebut akan mempengaruhi sifat fisik dan psikis anak misalnya tingkat kepercayaan diri dan kemandiriannya. Diantara aktivitas yang mendukung perkembangan kreativitas dalam bidang fisik adalah berkebun, memasak dan olahraga. Menurut Beetlestone (2012) dalam Ratnasari et al. (2016) berkebun membantu pesrkembangan fisik motorik anak melalui aktivitas dengan banyak gerak seperti menggali, mencangkul, membungkuk dan lainnya. Hal ini kemudian mempengaruhi perkembangan kreativitas anak tersebut. Memasak membantu perkembangan motorik halus anak melalui gerakan dan kegiatan saat memasak seperti memotong bahan masak, mengocok telur dan lainnya. Selain itu, memasak juga membantu perkembangan kognitif anak melalui aktivitas menakar bahan, ukuran bahan, warna dan rasa serta fungsi alat masak. Memasak juga membantu pekembangkan kreativitas anak dengan mencoba menggunakan ide dan imajinasinya atau berkreasi terhadap masakan (Lestari, 2019). Olahraga membantu perkembangan fisik motorik anak dan sifat kemandirian, tanggung jawab serta kreatif dan inovatif. Menurut Nasrulloh, anak usia 2-3 tahun dan 4-6 tahun baiknya memulai kegiatan olahraga yang sederhana seperti bermain bola, memanjat dan berayun, serta berlari dan melompat, dan bermain air. Sedangkan anak usia 6-12 tahun, kemampuan fisik seperti koordinasi mata, tangan dan kaki sudah lebih berkembang sehingga kegiatan olahraga yang dapat diperkenalkan sudah lebih beragam. Jenis olahraganya pun lebih menantang dan bersifat kompetitif. Berikut adalah jenis olahraganya mulai dari renang, bola basket, dan bulu tangkis.

Tema perancangan Pusat Kreativitas Anak di Pontianak adalah fasilitas yang ramah anak dan merangsang potensi anak. Fasilitas pendidikan yang ramah anak adalah fasilitas yang mencakup aspek keamanan dan kenyamanan. Menurut Putri (2017) adapun faktor-faktor yang mempengaruhi keamanan ruang untuk anak diantaranya penataan ruang dan perabot, penacapaian, material perabot serta penutup tanah atau lantai. Aspek kenyamanan diklasifikasikan menjadi 3 yaitu kenyamanan spasial, kenyamanan visual, dan kenyamanan termal. Berikut ini adalah faktor yang mempengaruhi kenyamanan menurut Hakim dalam Putri (2017) diantaranya sirkulasi, pengendalian terhadap temperatur dan bising, bentuk dan dimensi perabot, serta warna. Sedangkan aspek merangsang potensi terdiri dari 2 yaitu penggunaan warna dan dimensi kekontrasan. Menurut Sari (2004) kebutuhan ruang yang merangsang proses kreatif anak membutuhkan komposisi warna-warna hangat dan meriah seperti warna-warna hangat, warna kontras dan warna-warna terang. Warna-warna tersebut menciptakan kesan yang ceria, meriah dan semangat sehingga tercipta suasana ruang yang menyenangkan. Menurut Olds (2001) dalam Latif (2014) suatu ruang akan lebih mudah dipahami oleh anak-anak apabila ruangan tersebut memiliki kontras dalam pengaturan ruangnya. Dimensi kekontrasan meliputi dalam/luar, atas/bawah, terang/gelap, ada/tiada, order/misteri dan ekspos/tersembunyi.

\section{Metode}

Metode perancangan yang digunakan terdiri dari identifikasi masalah, pengumpulan data, pengolahan data/analisis, konsep bangunan, gambar pra rancangan hingga gambar rencana (Santosa, 2005). Tahap perancangan dimulai dari identifikasi masalah yaitu menentukan permasalahan dalam 
perancangan. Tahap selanjutnya adalah pengumpulan data yang terdiri dari data primer dan data sekunder. Data primer berisi data-data terkait tapak yang dapat diperoleh melalui survei dan observasi ke tapak secara langsung di Jl. Parit H. Husin 2 sedangkan data sekunder berisi teori-teori, standar atau aturan, data umum lokasi, serta studi kasus atau preseden bangunan yang sejenis yang diperoleh melalui ebook dan jurnal meliputi Data Arsitek dan Time Savers Standart for Building Types $2^{\text {nd }}$ Edition. Data-data yang telah terkumpul baik itu permasalahan atau pun potensi yang terdapat di tapak selanjutnya diolah dan dianalisis sehingga didapatkan konsep yang sesuai mulai dari analisis fungsi, analisis tapak, analisis struktur, analisis utilitas, dan analisis fisika bangunan. Setelah melakukan analisis terhadap data-data, maka diperoleh konsep bangunan sebagai solusi dari permasalahan dan potensi yang muncul saat menganalisis, secara terperinci meliputi konsep fungsi dan ruang, konsep tapak, konsep struktur, konsep utilitas, konsep fisika bangunan serta konsep skematik bangunan. Konsep yang didapat digunakan sebagai acuan dalam melengkapi gambar pra rancangan dan gambar rencana.

\section{Hasil dan Pembahasan}

Terdiri dari landasan konseptual yang merupakan analisis-analisis mulai dari analisis fungsi dan tema, analisis internal, analisis eksternal, analisis bentuk, analisis struktur serta analisis utilitas. Setelah analisis-analisis tersebut dilakukan menghasilkan konsep perancangan berupa konsep fungsi, konsep internal, konsep eksternal, konsep gubahan bentuk, konsep struktur, konsep utilitas serta hasil perancangan.

\section{Lokasi Perancangan}

Pemilihan site yang mengacu pada SNI 03-1733-2004 tentang Tata Cara Perencanaan Lingkungan Perumahan di Perkotaan yang mengatakan kriteria lokasi untuk fasilitas pendidikan sekolah dasar yaitu berada di dekat permukiman warga, dekat dengan fasilitas umum lainnya serta keamanan dan kenyamanan terjamin.

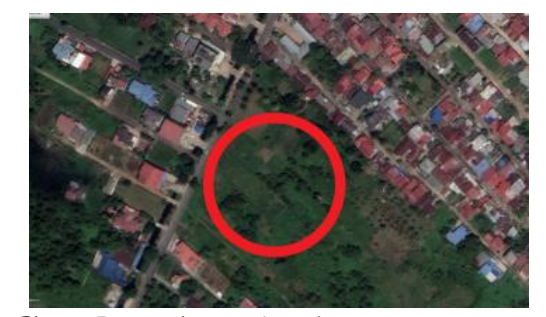

Gambar 1. Lokasi Perancangan

Sumber: Google Earth, 2021

Berdasarkan analisis, lokasi terpilih yaitu di Jl. Parit H. Husin 2 dengan beberapa kelebihan diantaranya berada di kawasan permukiman, berdekatan dengan fasilitas umum meliputi rumah sakit, mall, spbu, taman, masjid dan lainnya, serta keamanan dan kenyamanan terjamin serta jauh dari kawasan rawan kebakaran hutan. Adapun berdasarkan Rencana Tata Ruang Wilayah Kota Pontianak 2013-2033, lokasi site merupakan kawasan permukiman, serta memiliki ketentuan KDB paling tinggi sebesar $60 \%$, KLB paling tinggi sebesar 2,1\%, KDH paling rendah sebesar 40\%, GSB sebelah utara $15 \mathrm{~m}$, GSB sebelah selatan $9.5 \mathrm{~m}$, dan RMJ sebesar $17 \mathrm{~m}$. Lokasi site memiliki jaringan utilitas berupa jaringan air bersih dan kotor, jaringan listrik dan telepon, serta sirkulasi berupa jalan yang dapat dilalui oleh kendaraan roda dua, empat serta angkutan umum.

\section{Landasan Konseptual}

Analisis fungsi dilakukan untuk menentukan fungsi-fungsi yang terdapat pada Pusat Kreativitas Anak di Pontianak diantaranya fungsi utama, fungsi penunjang dan pendukung. Fungsi 
utama merupakan fungsi yang menaungi segala hal berkaitan dengan pendidikan. Fungsi pendidikan yang dimaksud adalah pendidikan nonformal yaitu jalur pendidikan di luar pendidikan nonformal yang ditujukan untuk mengembangkan kemampuan peserta didik, khususnya dalam hal ini adalah kreativitas anak. Adapun fungsi penunjang merupakan fungsi yang menaungi segala hal yang berkaitan dengan pengelolaan yaitu sistem operasional suatu bangunan sehingga dapat berfungsi sebagaimana mestinya. Fungsi pendukung merupakan fungsi yang menaungi segala hal yang berkaitan dengan komersial yaitu aktivitas perdagangan yang mendukung fungsi utama bangunan.

Analisis tema atau pendekatan dilakukan untuk menentukan tema yang digunakan pada Pusat Kreativitas Anak di Pontianak yaitu menekankan pada fasilitas yang ramah serta merangsang potensi anak dalam beraktivitas. Ramah dan merangsang potensi anak merupakan fasilitas dengan ruang dan lingkungan yang aman, nyaman, sehat dan kondusif, menerima anak apa adanya serta menghargai potensi anak. Berikut adalah alur pendekatan ramah anak dan merangsang potensi anak:

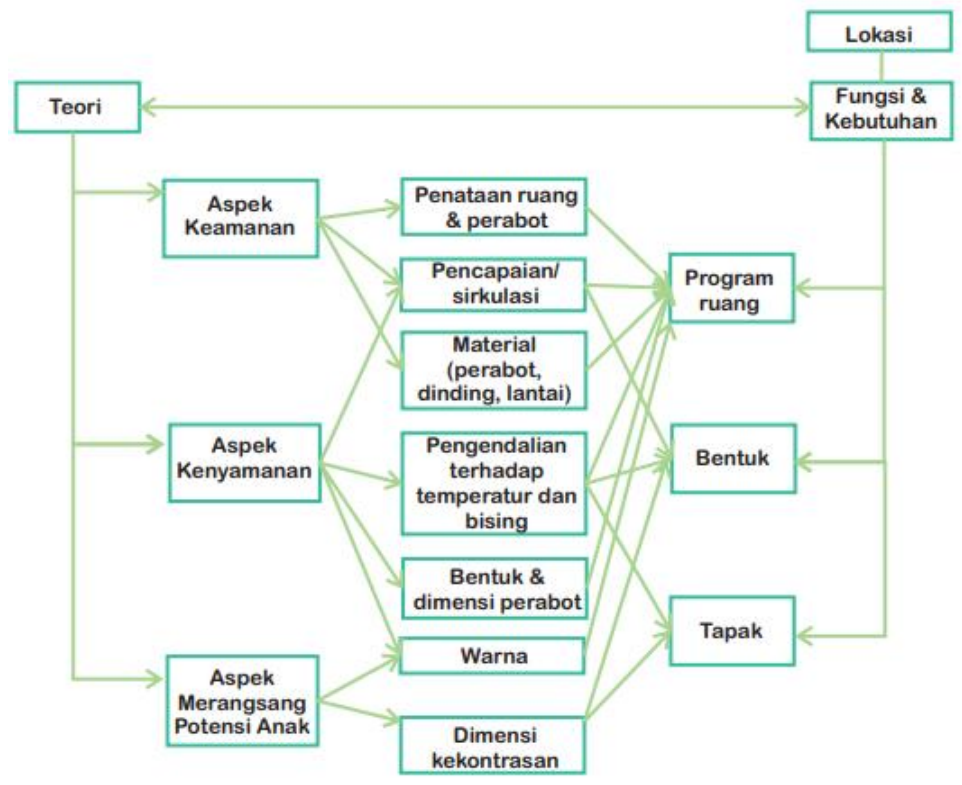

Gambar 2. Alur Pendekatan

Sumber: Penulis, 2021

Analisis internal merupakan penjelasan mengenai tata ruang dalam suatu bangunan yang terdiri atas analisis pelaku, kegiatan, kebutuhan ruang, hubungan ruang, organisasi ruang, persyaratan ruang hingga besaran ruang. Berdasarkan tabel 1, terdapat 44 ruang pada bangunan Pusat Kreativitas Anak di Pontianak. Ruang-ruang tersebut dikelompokan berdasarkan fungsi dan sifat ruang. Adapun jumlah total luas besaran ruang yang telah dihitung berdasarkan kapasitas manusia, standar perabot serta sirkulasi adalah $6.262,0896 \mathrm{~m}^{2}$. Berikut adalah tabel program ruang Pusat Kreativitas Anak di Pontianak:

Tabel 1. Program Ruang

\begin{tabular}{cllll}
\hline No & Fungsi & Nama ruang & Sifat Ruang & $\begin{array}{c}\text { Besaran } \\
\text { Ruang }\end{array}$ \\
\hline 1 & Penunjang & $\begin{array}{l}\text { Parkir pengunjung, } \\
\text { pengelola }\end{array}$ & Publik & $503 \mathrm{~m}^{2}$ \\
\hline 2 & Penunjang & Entrance & Publik & $52 \mathrm{~m}^{2}$ \\
\hline
\end{tabular}




\begin{tabular}{|c|c|c|c|c|}
\hline 3 & Penunjang & Hall & Publik & $52 \mathrm{~m}^{2}$ \\
\hline 4 & Utama & Ruang observasi & Publik & $20,8 \mathrm{~m}^{2}$ \\
\hline 5 & Utama & Loker & Semi Publik & $12,597 \mathrm{~m}^{2}$ \\
\hline 6 & Penunjang & Musholla (2 unit) & Semi Publik & $98,8 \mathrm{~m}^{2}$ \\
\hline 7 & Utama & Ruang dongeng (3-5 tahun) & Semi Privat & $99 \mathrm{~m}^{2}$ \\
\hline 8 & Utama & Ruang gambar (3-5 tahun) & Semi Publik & $102,78 \mathrm{~m}^{2}$ \\
\hline 9 & Utama & Ruang music (3-5 tahun) & Semi Privat & $81,6 \mathrm{~m}^{2}$ \\
\hline 10 & Utama & $\begin{array}{l}\text { Ruang main kolase (3-5 } \\
\text { tahun) }\end{array}$ & Semi Publik & $102,78 \mathrm{~m}^{2}$ \\
\hline 11 & Utama & $\begin{array}{l}\text { Ruang main playdough (3-5 } \\
\text { tahun) }\end{array}$ & Semi Publik & $102,78 \mathrm{~m}^{2}$ \\
\hline 12 & Utama & Ruang balok (3-5 tahun) & Semi Publik & $99 \mathrm{~m}^{2}$ \\
\hline 13 & Utama & $\begin{array}{l}\text { Ruang bermain outdoor ( } 3 \text { - } \\
5 \text { tahun) }\end{array}$ & Publik & $226,1 \mathrm{~m}^{2}$ \\
\hline 14 & Utama & Ruang pameran & Semi Publik & $52 \mathrm{~m}^{2}$ \\
\hline 15 & Utama & Ruang pertunjukan & Semi Publik & $52 \mathrm{~m}^{2}$ \\
\hline 16 & Utama & Ruang gambar (6-12 tahun) & Semi Privat & $\begin{array}{l}107,276 \\
\mathrm{~m}^{2}\end{array}$ \\
\hline 17 & Utama & Ruang music gesek/petik & Semi Privat & $141,44 \mathrm{~m}^{2}$ \\
\hline 18 & Utama & Ruang music tekan & Semi Privat & $141,44 \mathrm{~m}^{2}$ \\
\hline 19 & Utama & Ruang music pukul & Semi Privat & $141,44 \mathrm{~m}^{2}$ \\
\hline 20 & Utama & Ruang tari & Semi Privat & $201 \mathrm{~m}^{2}$ \\
\hline 21 & Utama & Ruang bulu tangkis & Semi Publik & $245,22 \mathrm{~m}^{2}$ \\
\hline 22 & Utama & Ruang basket & Semi Publik & $936 \mathrm{~m}^{2}$ \\
\hline 23 & Utama & $\begin{array}{l}\text { Ruang ganti/loker olahraga } \\
\text { ( } 2 \text { unit) }\end{array}$ & Semi Publik & $35,36 \mathrm{~m}^{2}$ \\
\hline 24 & Utama & Ruang memasak (indoor) & Semi Privat & $205,92 \mathrm{~m}^{2}$ \\
\hline 25 & Utama & Area kebun (outdoor) & Semi Publik & $198 \mathrm{~m}^{2}$ \\
\hline 26 & Penunjang & Toilet (4 unit) & Servis & $208 \mathrm{~m}^{2}$ \\
\hline 27 & Penunjang & Ruang kepala & Privat & $9,698 \mathrm{~m}^{2}$ \\
\hline 28 & Penunjang & $\begin{array}{l}\text { Ruang Divisi Administrasi } \\
\text { Umum }\end{array}$ & Privat & $14,885 \mathrm{~m}^{2}$ \\
\hline
\end{tabular}




\begin{tabular}{|c|c|c|c|c|}
\hline 29 & Penunjang & Ruang Arsip & Privat & $5,889 \mathrm{~m}^{2}$ \\
\hline 30 & Penunjang & Ruang Divisi Keuangan & Privat & $14,885 \mathrm{~m}^{2}$ \\
\hline 31 & Penunjang & Ruang Tamu & Semi Privat & $8,645 \mathrm{~m}^{2}$ \\
\hline 32 & Penunjang & Ruang Staff & Privat & $86,19 \mathrm{~m}^{2}$ \\
\hline 33 & Penunjang & Ruang Panel MEE & Servis & $\begin{array}{l}12 \mathrm{~m}^{2} / \\
\text { unit }\end{array}$ \\
\hline 34 & Penunjang & Ruang Genset & Servis & $24 \mathrm{~m}^{2}$ \\
\hline 35 & Penunjang & Ruang Mesin AC & Servis & $12 \mathrm{~m}^{2}$ \\
\hline 36 & Penunjang & $\begin{array}{l}\text { Ruang Komunikasi \& } \\
\text { Informasi }\end{array}$ & Servis & $6,63 \mathrm{~m}^{2}$ \\
\hline 37 & Penunjang & Ruang Keamanan \& CCTV & Servis & $6,63 \mathrm{~m}^{2}$ \\
\hline 38 & Penunjang & Ruang Cleaning Servis & Servis & $11,7 \mathrm{~m}^{2}$ \\
\hline 39 & Penunjang & Gudang & Servis & $25 \mathrm{~m}^{2}$ \\
\hline 40 & Penunjang & Pos Jaga & Servis & $6,5 \mathrm{~m}^{2}$ \\
\hline 41 & Penunjang & TPS (bak sampah) & Servis & $6 \mathrm{~m}^{3}$ \\
\hline 42 & Pendukung & Ruang Tunggu & Publik & $52 \mathrm{~m}^{2}$ \\
\hline 43 & Pendukung & Foodcourt/cafeteria & Publik & $198,25 \mathrm{~m}^{2}$ \\
\hline 44 & Pendukung & Toy and stationery store & Publik & $141,96 \mathrm{~m}^{2}$ \\
\hline & & & Sirkulasi $30 \%$ & $\begin{array}{l}1.445,0976 \\
\mathrm{~m}^{2}\end{array}$ \\
\hline & & & Total & $\begin{array}{l}6.626,0896 \\
\mathrm{~m}^{2}\end{array}$ \\
\hline
\end{tabular}

Sumber: Penulis, 2021

Organisasi ruang disusun berdasarkan hubungan ruang yang telah dianalisis sebelumnya sehingga terjadi pengelompokan ruang-ruang memiliki hubungan baik erat maupun tidak erat. Ruang-ruang yang berhubungan disusun berdekatan atau berada pada sirkulasi yang sama. Sedangkan ruang-ruang yang tidak berhubungan disusun berjauhan atau tidak berada pada sirkulasi yang sama. Ruang-ruang anak untuk usia 3-5 tahun berada pada sirkulasi yang sama dan berdekatan misalnya ruang gambar, ruang dongeng, ruang kolase, ruang lilin dan lainnya. Hal ini juga dilakukan pada ruang olahraga seperti lapangan basket dan lapangan bulutangkis berada pada sirkulasi yang sama dengan ruang-ruang outdoor lainnya seperti taman bermain outdoor dan kebun. Berikut ini adalah organisasi ruang: 


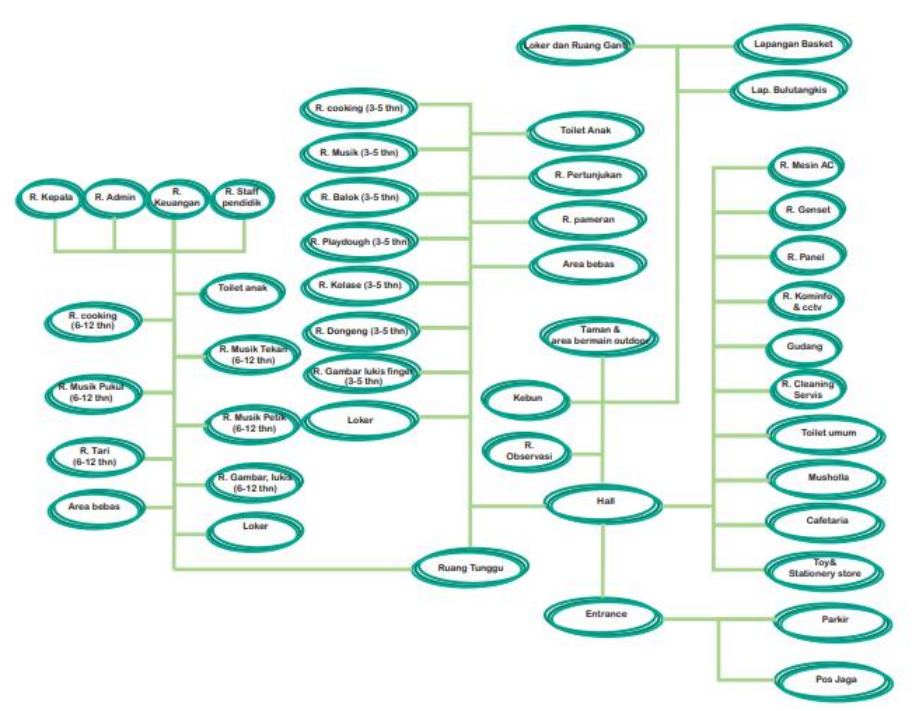

Gambar 3. Organisasi Ruang

Sumber: Penulis, 2021

Analisis eksternal penjelasan mengenai tata ruang luar suatu bangunan yang terdiri atas analisis perletakan, analisis orientasi, analisis sirkulasi, analisis vegetasi, dan analisis zonasi. Analisis perletakan mengacu pada peraturan mengenai GSB, GSS, dan RMJ, posisi matahari/iklim, kebisingan dan kualitas udara, serta sirkulasi. Bagian yang berwarna merah merupakan letak bangunan di dalam site. Konsep perletakan bangunan diantaranya yaitu bangunan diletakan pada bagian dalam site, luas lahan tidak dibangun secara keseluruhan, tetapi dimanfaatkan untuk fungsi lain seperti area hijau dan area parkir serta sirkulasi dan pergerakan di dalam site, terdapat space pada bagian barat untuk area parkir, terdapat vegetasi peneduh dibagian barat site.

Analisis orientasi mengacu pada view kawasan sekitar, arah datangnya angin, serta sirkulasi. Konsep orientasi bangunan diantaranya yaitu bangunan menghadap J1. Parit H Husin II, bukaan pada bagian semua bagian meliputi utara, timur dan selatan, terdapat vegetasi peneduh dibagian barat site. Analisis sirkulasi mengacu pada sirkulasi, posisi matahari, serta letak jaringan utilitas seperti tiang listrik dan telepon. Konsep sirkulasi diantaranya yaitu terdapat 2 akses menuju bangunan yaitu akses masuk dan akses keluar, akses masuk berada di sisi barat site sedangkan akses keluar berada di sisi timur site, jaringan sirkulasi bersifat satu arah. Analisis vegetasi mengacu pada kebisingan dan kualitas udara, posisi matahari, serta sirkulasi. Konsep vegetasi diantaranya yaitu di sisi utara dan selatan terdapat vegetasi yaitu pucuk merah sebagai peredam bising dan bau, di sisi timur dan barat terdapat vegetasi yaitu pohon tabebuya sebagai peneduh, di sekeliling site terdapat vegetasi yaitu pohon glodogan tiang sebagai penunjuk arah. Analisis zonasi mengacu pada view kawasan sekitar, posisi matahari, sirkulasi serta kebisingan. Zona warna ungu merupakan zona public, zona warna biru merupakan zona semi public, zona warna kuning merupakan zona semi privat, zona warna merah merupakan zona privat serta zona warna oranye merupakan zona servis. Konsep zonasi diantaranya yaitu zona publik terletak di sisi utara atau bagian depan site, zona servis terletak di sisi barat site, zona semi publik, semi privat, dan privat terletak di sisi timur dan selatan site. Berikut ini adalah analisis tapak: 


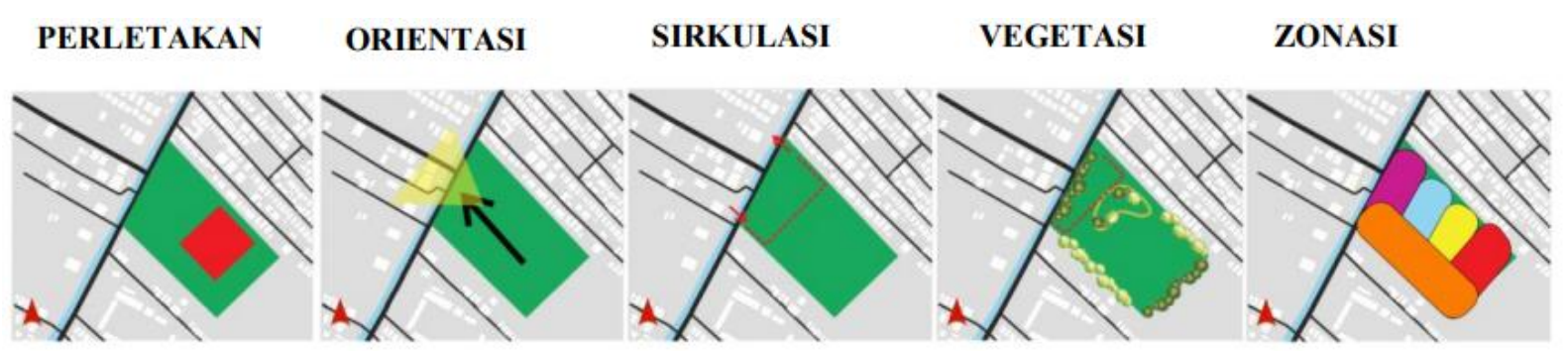

Gambar 4. Analisis Tapak

Sumber: Penulis, 2021

\section{Konsep Gubahan Bentuk}

Gubahan bentuk bangunan yang mengacu pada analisis internal dan eksternal yang telah dilakukan sebelumnya mulai dari fungsi ruang, perletakan, posisi matahari hingga arah datangnya angin. Bentuk bangunan terinspirasi dari mainan anak-anak yaitu balok atau stacking block. Mainan ini merupakan mainan dengan berbagai macam bentuk salah satunya silindris dan juga memiliki warna yang beragam. Bentuk yang dinamis dimaksudkan agar tidak kaku dan monoton serta permainan warna yang beragam memberikan kesan menyenangkan dan kreatif yang mencerminkan sifat anak-anak. Sisi bangunan yang menghadap barat diberi sun shading untuk mereduksi panas matahari yang masuk. Sun shading diberi warna yang beragam sehingga terlihat lebih menarik. Berikut ini adalah tranformasi bentuk:

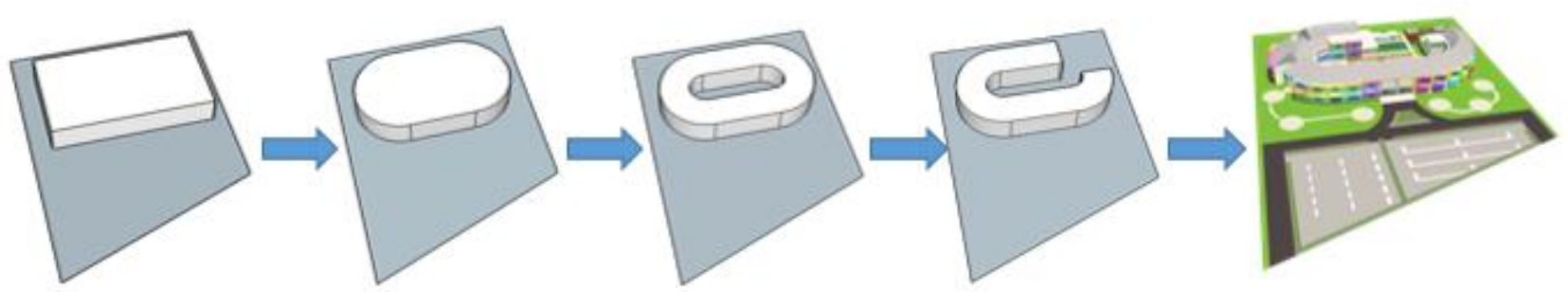

Gambar 5. Gubahan Bentuk

Sumber: Penulis, 2021

\section{Konsep Struktur}

Konsep struktur bangunan yang mengacu pada analisis yang telah dilakukan sebelumnya mulai dari struktur bawah yaitu pondasi tiang pancang, plat lantai serta struktur atas mulai dari rangka bangunan yaitu kolom dan balok serta rangka atap. Pemilihan jenis pondasi didasarkan oleh jenis dan kontur tanah di lokasi site perancangan yaitu Pontianak umumnya jenis tanah gambut. Karakteristik tanah gambut memiliki tanah keras yang berada jauh di kedalaman tanah sehingga pondasi dalam yaitu tiang pancang sangat tepat untuk digunakan. Sistem struktur yang digunakan adalah struktur rangka beton yang terdiri dari kolom dan balok. Pemilihan jenis sistem struktur ini menyesuaikan dengan kebutuhan yaitu bangunan bertingkat rendah. Adapun atap menggunakan jenis atap pelana dan dak beton. Pemilihan jenis atap ini menyesuaikan dengan iklim lokasi site yaitu Pontianak memiliki curah hujan yang cukup tinggi. Atap pelana yang memiliki kemiringan, tepat untuk digunakan sehingga air hujan cepat turun ke tanah. Jenis rangka atap yang digunakan adalah baja ringan dengan penutup atap genteng onduvilla.

\section{Konsep Utilitas}

Konsep utilitas terdiri atas sistem jaringan air, sistem jaringan listrik, sistem tata udara dan sistem keamanan bangunan. Sistem distribusi air bersih menggunakan sistem upfeed yang mengalirkan air dari PDAM menuju ground tank ke ruang-ruang seperti ruang kelas khususnya yang memiliki wastafel, toilet, cafeteria serta kebun. Sumber air kotor atau limbah terdiri atas ruang kelas, 
toilet, dan cafeteria. Ruang kelas dan cafeteria menghasilkan limbah cair sedangkan toilet menghasilkan limbah padat dan cair. Semua limbah dibuang menuju STP, khusus limbah yang berasal dari cafeteria disaring terlebih dahulu ke grease trap.

Sistem jaringan terdiri dari terdiri dari jaringan listrik, jaringan komunikasi dan jaringan informasi. Sumber listrik berasal dari PLN dan genset yang diteruskan ke ruang panel utama. Dari ruang panel utama, listrik diteruskan ke ruang-ruang yang membutuhkan seperti ruang mesin AC dan ruang CCTV/Kominfo. Sistem jaringan komunikasi terdiri dari jaringan telepon dan wifi. Jaringan wifi terhubung ke sistem komunikasi modem, router, access point dan alat komunikasi lainnya seperti komputer dan telepon genggam.

Sistem tata udara menggunakan sistem AC Central jenis VRV. Sistem ini terdiri dari outdoor unit, pipa refrigerant dan indoor unit. Outdoor unit berada di atas ruang mesin AC tepatnya berada di atap dak yang mengalirkan udara dingin ke indoor unit tiap ruang melalui pipa refrigerant. Adapun ruang yang menggunakan AC meliputi ruang yang bersifat tertutup yaitu ruang-ruang anak, kantor pengelola, cafeteria dan toy and stationery store.

Sistem keamanan bangunan terbagi menjadi 2 yaitu kebakaran dan penangkal petir. Sistem keamanan kebakaran yang digunakan diantaranya yaitu hidran dan alat pemadam api ringan (APAR). Sumber air bersih mengalirkan air ke hidran gedung dan hidran halaman. Adapun sistem keamanan penangkal petir yang digunakan diantaranya yaitu sistem franklin. Lightning rods atau alat penerima diletakan di atas atap bangunan dengan jarak tertentu.

\section{Hasil Perancangan}

Hasil perancangan merupakan gambar pra perancangan yang didapat dari hasil akhir landasan konseptual dan konsep perancangan yang telah dilakukan sebelumnya. Gambar pra perancangan terdiri dari siteplan, denah, tampak, potongan serta suasana eksterior dan interior.

Gambar 6 menampilkan siteplan bangunan di dalam kawasan site perancangan. Pada gambar ini terlihat bangunan perancangan terletak di bagian dalam site, sedangkan pada bagian depan dimanfaatkan sebagai lahan parkir. Adapun ruang-ruang di sekitar bangunan yang tidak terbangun dimanfaatkan sebagai area hijau dan taman. Berikut ini adalah gambar siteplan:

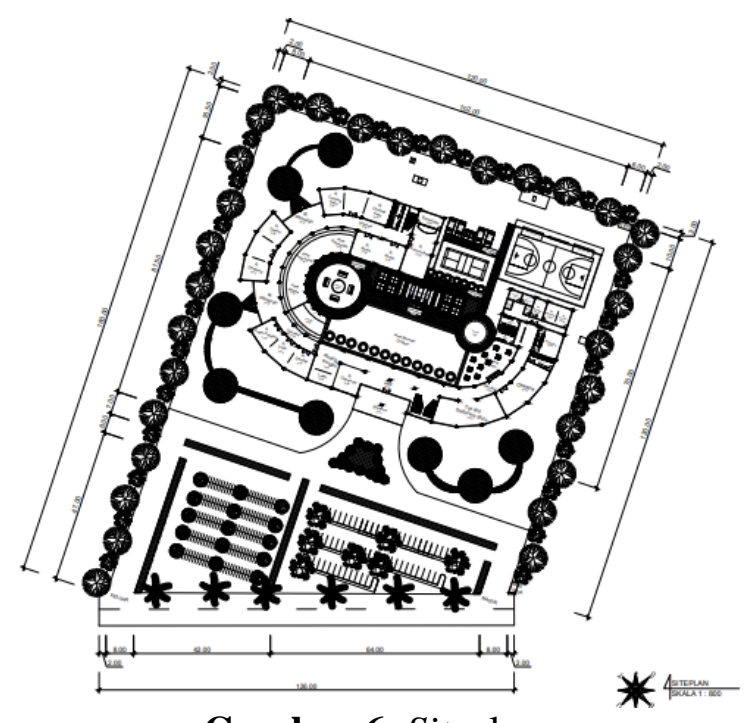

Gambar 6. Siteplan

Sumber: Penulis, 2021

Gambar 7 menampilkan tata ruang dalam bangunan perancangan. Pada lantai dasar, ruangruang dikhususkan untuk anak-anak usia 3-5 tahun dengan alasan anak umur tersebut dianggap belum bisa mengakses tangga secara mandiri. Ruang-ruang pada lantai ini bersifat publik hingga 
semi publik meliputi area bermain outdoor, cafeteria, toy and stationery store hingga ruang-ruang anak usia 3-5 tahun. Terdapat 2 entrance yang berfungsi sebagai akses masuk dan akses keluar yang terletak di bagian depan. Berikut ini adalah gambar denah lantai dasar:

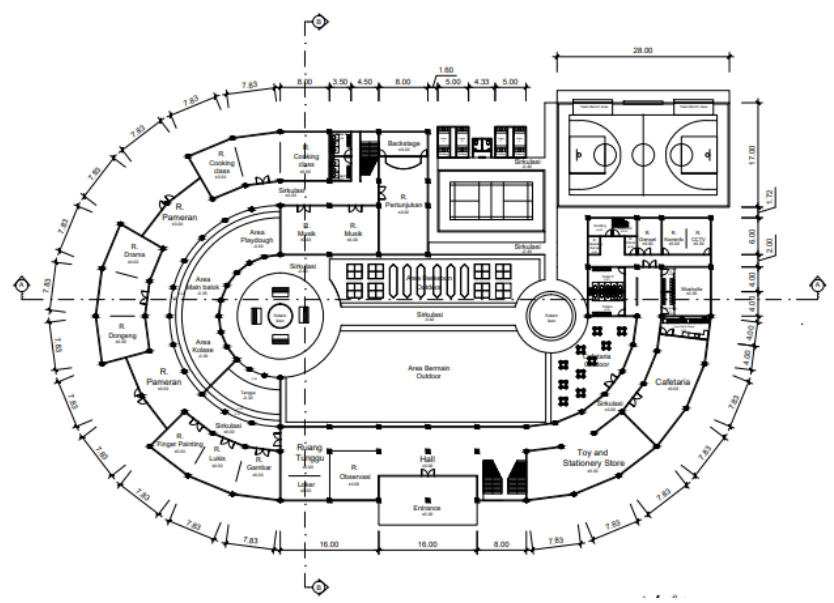

Gambar 7. Denah Lantai Dasar

Sumber: Penulis, 2021

Gambar 8 menampilkan tata ruang dalam bangunan perancangan. Pada lantai 1, ruang-ruang dikhususkan untuk anak-anak usia 6-12 tahun dengan alasan anak umur tersebut dianggap sudah bisa mengakses tangga secara mandiri. Ruang-ruang pada lantai ini bersifat semi privat hingga privat meliputi kantor pengelola, ruang staff, hingga ruang-ruang anak usia 6-12 tahun. Ruang-ruang tersebut diletakan di lantai 1 agar privasi ruang tetap terjaga. Berikut ini adalah gambar denah lantai $1:$

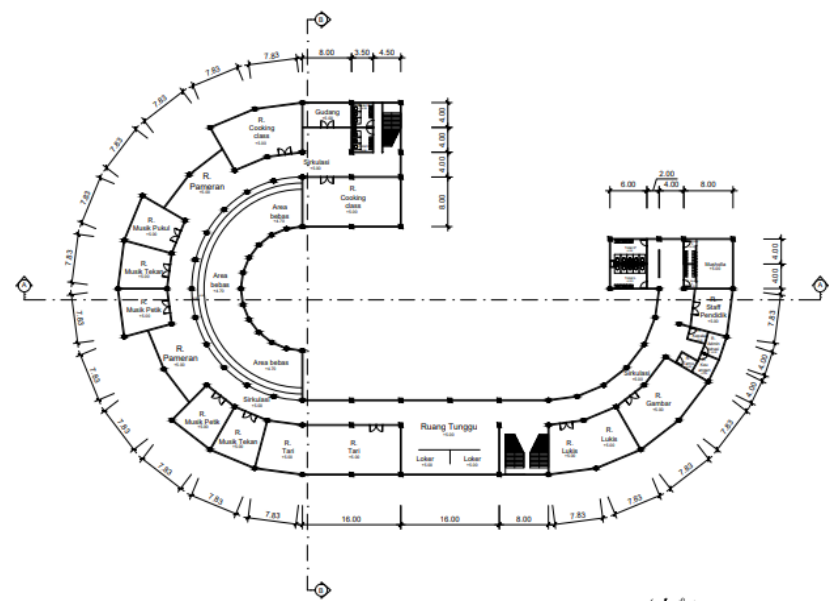

Gambar 8. Denah Lantai 1

Sumber: Penulis, 2021

Gambar 9 menampilkan view fasad bangunan terhadap kawasan sekitarnya. Bangunan menggunakan permainan warna dan sun shading yang ditempatkan pada fasad sedemikian rupa. Terdapat perbedaan fasad di kedua sisi bangunan. Sisi timur yang menghadap matahari pagi, didesain dengan bukaan besar berupa kaca untuk memaksimalkan pencahayaan alami. Adapun sisi barat yang menghadap matahari sore, didesain dengan sun shading agar panas matahari tidak masuk secara berlebihan. Terdapat dua jenis sun shading agar tampilan fasad tidak monoton dan kaku. Berikut ini adalah gambar tampak: 


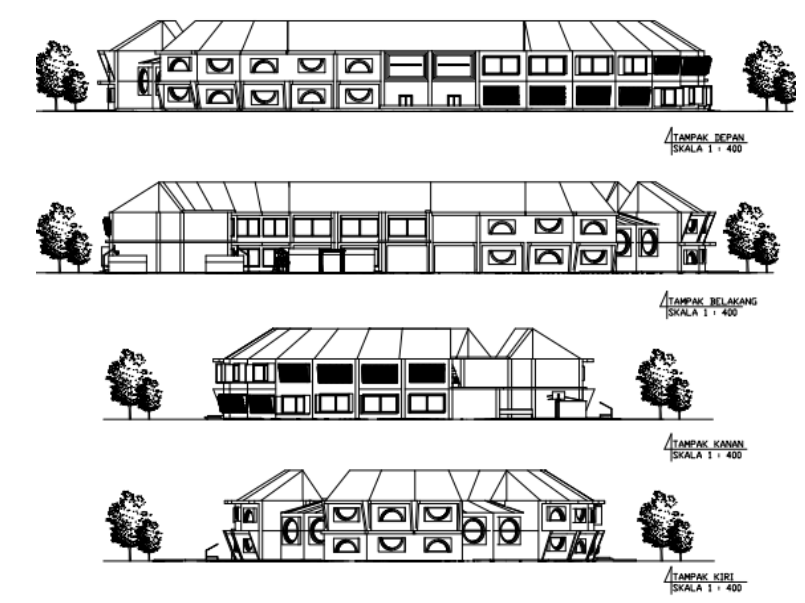

Gambar 9. Tampak

Sumber: Penulis, 2021

Gambar 10 menampilkan potongan bangunan terhadap kawasan sekitarnya. Bangunan menggunakan struktur rangka beton bertulang dengan pondasi tiang pancang. Adapun rangka atap yang digunakan adalah rangka baja ringan. Penutup atap menggunakan genteng onduvilla yang cocok dikombinasikan dengan rangka baja ringan. Berikut ini adalah gambar potongan:
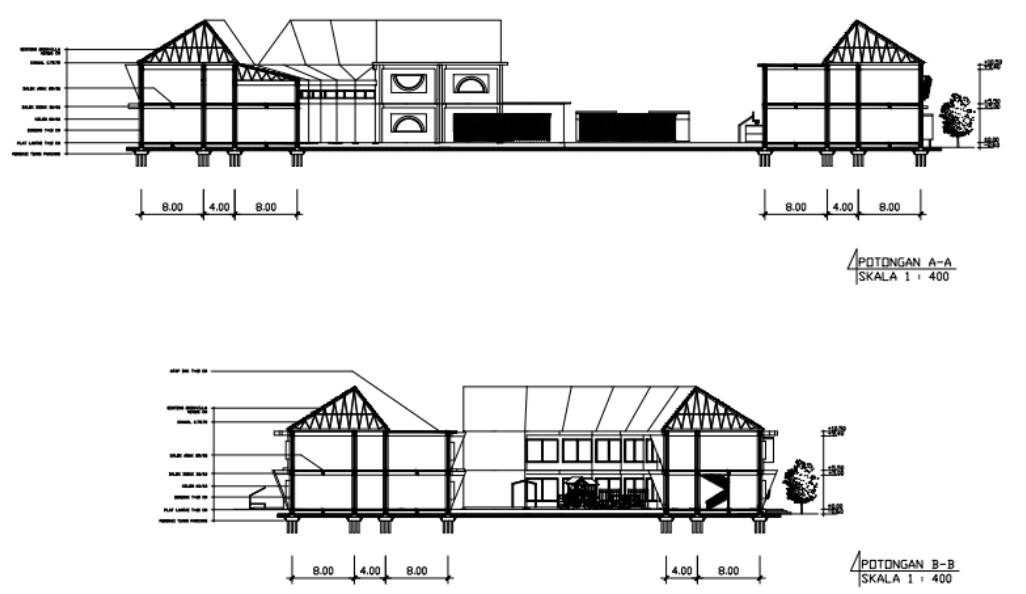

Gambar 10. Potongan

Sumber: Penulis, 2021

Gambar 11 menampilkan suasana ruang luar bangunan di dalam site. Terdapat area drop off pada entrance masuk bangunan. Diantara jalur kendaraan terdapat vegetasi sebagai estetika dan area hijau. Berikut ini adalah suasana tampak depan bangunan:

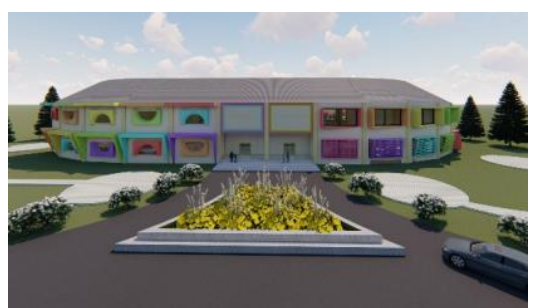

Gambar 11. Suasana Tampak Depan

Sumber: Penulis, 2021 
Gambar 12 menampilkan suasana ruang luar bangunan di dalam site. Area kebun terletak di bagian outdoor dalam atau tengah-tengah bangunan. Di sekeliling area kebun ditanami vegetasi sebagai pagar hidup. Penutup lantai area kebun dilapisi dengan batu kerikil halus untuk menghindari kecelakaan pada anak-anak. Berikut ini adalah suasana area kebun:

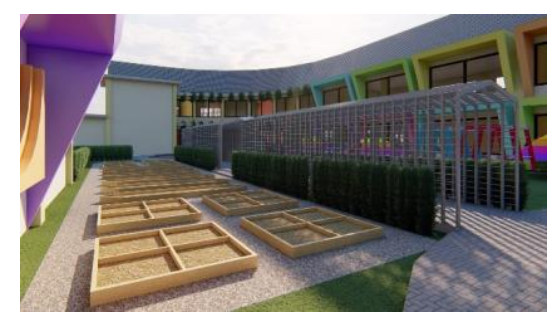

Gambar 12. Suasana Area Kebun

Sumber: Penulis, 2021

Gambar 13 menampilkan suasana ruang dalam bangunan di dalam site. Terdapat perwujudan aspek-aspek pendekatan yang diterapkan pada desain diantaranya perbedaan tinggi rendah pada plafon dengan bentuk geometris yaitu heksagonal. Penggunaan warna yang beragam pada interior dengan warna-warna yang cerah. Penutup lantai menggunakan vinyl kayu yang aman dan tidak licin. Adanya wall panel yang tidak hanya berfungsi sebagai elemen penyerap bunyi atau bising tetapi juga sebagai estetika. Perabot yang digunakan tidak bersudut tajam dan dimensinya menyesuaikan anakanak. Berikut ini adalah suasana interior ruang gambar:

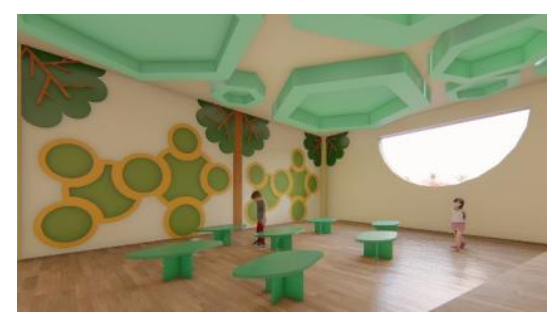

Gambar 13. Suasana Ruang Gambar

Sumber: Penulis, 2021

Gambar 14 menampilkan suasana ruang dalam bangunan di dalam site. Ruang kolase, lilin dan balok diletakan di ruang terbuka dengan alasan ruang-ruang ini memiliki sifat kegiatan yang tidak memerlukan konsentrasi tinggi sehingga dapat dilakukan sambil bermain. Ruang yang dibutuhkan adalah ruang dengan sirkulasi yang lebar sehingga anak pergerakan anak tidak terbatas. Terdapat perwujudan aspek-aspek pendekatan yang diterapkan pada desain diantaranya penutup lantai menggunakan vinyl kayu yang aman dan tidak licin. Sirkulasi yang didesain lebar sehingga menghasilkan ruang yang luas dan bebas hambatan. Berikut ini adalah suasana interior ruang kolase, lilin dan balok:

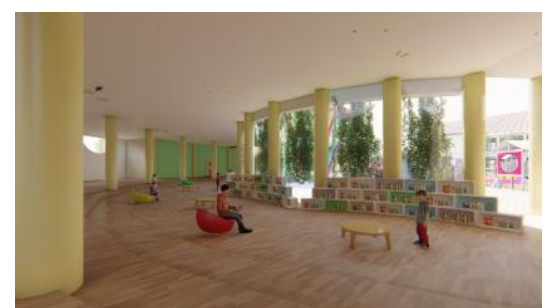

Gambar 14. Suasana Ruang Kolase, Lilin, Balok Sumber: Penulis, 2021 
Gambar 15 menampilkan suasana ruang dalam bangunan di dalam site. Ruang memasak membutuhkan beberapa perabot seperti meja dan wastafel. Terdapat perwujudan aspek-aspek pendekatan yang diterapkan pada desain diantaranya perbedaan tinggi rendah pada plafon dengan bentuk geometris yaitu heksagonal. Penutup lantai menggunakan vinyl kayu yang aman dan tidak licin. Adanya wall panel dengan warna yang berbeda dengan ruang-ruang sebelumnya. Berikut ini adalah suasana interior ruang memasak:

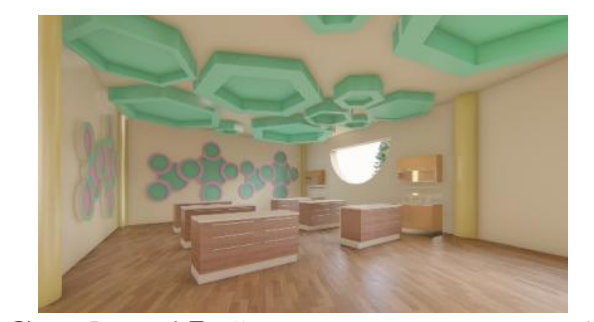

Gambar 15. Suasana Ruang Masak

Sumber: Penulis, 2021

Gambar 16 menampilkan suasana ruang dalam bangunan di dalam site. Ruang musik diletakan di ruang tertutup dengan alasan ruang ini memiliki sifat kegiatan yang privasi dan membutuhkan konsentrasi yang tinggi. Terdapat perwujudan aspek-aspek pendekatan yang diterapkan pada desain diantaranya perbedaan tinggi rendah pada plafon dengan bentuk geometris yaitu heksagonal. Penutup lantai menggunakan vinyl kayu yang aman dan tidak licin. Adanya wall panel yang tidak hanya berfungsi sebagai elemen penyerap bunyi atau bising tetapi juga sebagai estetika. Berikut ini adalah suasana interior ruang musik:

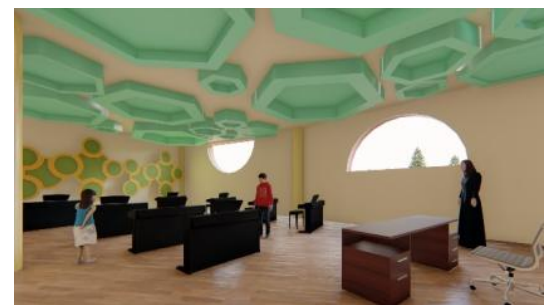

Gambar 16. Suasana Ruang Musik

Sumber: Penulis, 2021

\section{Kesimpulan}

Perancangan Pusat Kreativitas Anak di Pontianak merupakan sebuah fasilitas yang mewadahi kegiatan anak dalam mengembangkan kreativitas dengan pengguna anak-anak usia 3-5 tahun dan 612 tahun. Kedua kelompok usia tersebut memiliki kebutuhan ruang dan aktivitas yang berbeda. Penekanan perancangan Pusat Kreativitas Anak di Pontianak adalah ramah anak dan merangsang potensi anak. Pendekatan diterapkan ke dalam perancangan yang disesuaikan dengan fungsi serta kebutuhan anak di dalam ruang tersebut. Mulai dari aspek keamanan yang mencakup penataan ruang dan perabot, akses/pencapaian, material perabot, serta material penutup lantai atau tanah. Sedangkan aspek kenyamanan mencakup sirkulasi atau penataan perabot, pengendalian terhadap temperatur ruang, kebisingan, bentuk atau dimensi perabot yang menyesuaikan standar anak, serta penggunaan warna. Adapun aspek merangsang potensi anak mencakup penggunaan warna dan dimensi kekontrasan suatu ruang serta dimensi kekontrasan suatu ruang. Konsep ini menghasilkan 1 massa bangunan yang dinamis dengan bentuk lingkaran yang telah mengalami penambahan dan pengurangan bentuk. Perancangan Pusat Kreativitas Anak di harapkan dapat mewadahi kegiatan anak dengan yang aman, nyaman, sehat dan kondusif, menerima anak apa adanya, dan menghargai potensi anak. 


\section{Ucapan Terima Kasih}

Puji syukur kepada Allah SWT atas rahmat dan karunia-Nya tulisan ini dapat diselesaikan dan ucapan terima kasih kepada orang tua yang selalu mendukung, kepada para dosen yaitu Ibu Lestari, S.T., M.T, selaku dosen pembimbing utama; Bapak Irwin, S.T., M.T., selaku dosen pembimbing pendamping; Ibu Bontor Jumaylinda Gultom, S.T., M.T., selaku dosen penguji utama; dan Bapak M. Nurhamsyah, S.T., M.Sc., selaku dosen penguji pendamping yang telah memberikan bimbingan, saran, masukan dan kritik serta kepada pihak-pihak lain yang tidak dapat disebutkan satu persatu.

\section{Daftar Acuan}

Abidin, Y. (2013). Strategi Mendongeng Kreatif, Cerdas, dan Edutaimen. Cakrawala Dini Jurnal Pendidikan Anak Usia Dini, 4(1)

Ariani, J; Chumdari; Rahmawati, A. (2013). Upaya Meningkatkan Kreativitas Menggambar Anam Melalui Media Pasir Warna pada Anak Kelompok B1 TK Islam Permata hati Jajar Laweyan Surakarta Tahun Ajaran 2013/2014. Kumara Cendekia, 42(6), 816-822

Atmiasri, W. T. (2019). Pusat Kreativitas Anak Di Semarang [Universitas Katolik Soegijapranata]. http://repository.unika.ac.id/15427/1/12.11.0050 LTP R. Marthian Sularso COVER.pdf

Devi, F. P. (2014). Peningkatan Kreativitas Melalui Kegiatan Kolase Pada Anak Kelompok B2 Di TK ABA Keringan Kecamatan Turi Kabupaten Sleman. In Tetrahedron Letters (Vol. 55). Universitas Negeri Yogyakarta

Fakhriyani, D. V. (2016). Pengembangan Kreativitas Anak Usia Dini. Wacana Didaktika, 4(2), 193-200. https://doi.org/10.31102/wacanadidaktika.4.2.193-200

Fauziah, H. (2017). Upaya Meningkatkan Kreativitas Anak Usia 5-6 Tahun Melalui Bermain Balok DI RA. Nurul Hasanah JL. Andasari Kel. Terjun Medan Marelan. In Journal of Chemical Information and Modeling (Vol. 53, Issue 9). Universitas Islam negeri Sumatera Utara

Kemendikbud. (2012). Kurikulum 2013 Kompetensi Dasar Sekolah Dasar (SD)/Madrasah Ibtidaiyah (MI). In Http://Kemdikbud.Go.Id/(Issue Mei). http://kemdikbud.go.id/main/?lang=id

Latif, F. (2014). Pentingnya Interior Playgroup dalam Mengoptimalkan Kreativitas Anak Prasekolah. Humaniora, 5(1), 367. https://doi.org/10.21512/humaniora.v5i1.3035

Lestari, D. P. (2019). Peningkatan Kreatifitas Melalui Funcooking pada Kelompok A RA Az Zahra Kebayoran Baru Jakarta Selatan. Jurnal PG-PAUD Trunojoyo: Jurnal Pendidikan Dan Pembelajaran Anak Usia Dini, 6(1), 1828. https://doi.org/10.21107/pgpaudtrunojoyo.v6i1.5370

Nasrulloh, A. Membangun Kemandirian Anak-Anak, Remaja, dan Dewasa untuk Olahraga. Fakultas Ilmu Keolahragaan. Universitas Negeri Yogyakarta

Putri, M. R. (2017). Standar Keamanan dan Kenyamanan Ruang Bermain Anak Usia Pra Sekolah pada Lahan Terbatas. Diakses 29 Oktober 2020, https://issuu.com/monicarosary/docs/laporan_akhir_seminar

Rahmat, S. T., \& Sum, T. A. (2017). Mengembangkan Kreativitas Anak. Jurnal Pendidikan Dan Kebudayaan Missio, 9(2), 111-123

Ratnasari, T., Sujana, Y., Kom, S., Kom, M., Rahma, A., \& Pudyaningtyas, S. (2016). Pengaruh Penerapan Kegiatan Berkebun Terhadap Perkembangan Fisik Motorik Anak. Kumara Cendekia, 6(2), 66-74

Santosa, A. (2005). Pendekatan Konseptual Dalam Proses Perancangan Interior. Dimensi Interior, 3(2), 111-123. http://puslit2.petra.ac.id/ejournal/index.php/int/article/view/16387

Sari, S. M. (2004). Peran Warna Interior Terhadap Perkembangan Dan Pendidikan Anak di Taman Kanak-Kanak. Dimensi Interior, $2(1), \quad 22-36$. https://www.google.com/url?sa=t\&rct=j\&q=\&esrc=s\&source=web\&cd=12\&ved=0CCEQFjABOApqFQoTCOug 9vnlzcgCFRWQjgodQ9kDSA\&url=http://dimensiinterior.petra.ac.id/index.php/int/article/download/16244/16236 \&usg=AFQjCNHDVHqMKmSSteJCIYCTxMDT3VXSzg\&bvm=bv.105454873,d.c2

Setyaningsih, W. (2004). Children Center di Solo Baru sebagai Pusat Pengembangan Kreativitas Anak. Tugas Akhir. Jurusan Arsitektur. Fakultas Teknik Universitas Sebelas Maret. Surakarta

Sit, M; Khadijah; Nasution, F. (2016). Pengembangan Kreativitas Anak Usia Dini (Teori dan Praktik). Perdana Publishing

Yulianto; Nurjannah; Haq, M. Z. (2018). Pengembangan Kreatifitas Melalui Musik Pada Anak Usia Dini Studi Kasus di TK ABA Priwulung Sleman Yogyakarta. Al Athfal, 1(2), 112-134

Yulianto, A. (2016). Pendidikan Ramah Anak: Studi Kasus SDIT Nur Hidayah Suryakarta. At-Tarbawi, 1(2), 137-156 